\title{
DISEMINASI HAND SANITIZER MAMPU MENGURANGI PERTUMBUHAN MIKROBA DI SIANTAR ESTATE
}

\author{
Herna Febrianty Sianipar ${ }^{1 *}$, Theresia Monika Siahaan², Mungkap Mangapul \\ Siahaan $^{3}$, Maryanto Saragih ${ }^{4}$ \\ 1,2Universitas HKBP Nommensen Pematangsiantar \\ *Penulis Koresponsensi, email: hernafebriantysianipar@uhnp.ac.id
}

\begin{abstract}
The COVID-19 pandemic can threaten human lives and can spread massively if there are no comprehensive preventive measures in all countries including Indonesia. Various efforts are known to be made to prevent the spread of COVID, including the use of hand sanitizers, which are antiseptic fluids capable of killing viruses, bacteria, and fungi found in the air, tools, and the human body, including hands. . The method of activities carried out in this community service is counseling using the lecture method using power point slide media which contains an explanation of the importance of a hand sanitizer and demonstrating directly with a hand swab from a community before and after using a handsanitizer and then scratching it on PDA media (Potato Dextrose Agar). The conclusion of this community service is that the community understands the importance of using a handsanitizer before carrying out activities because they see directly the growing bacteria.
\end{abstract}

\section{Keywords: handsanitizer, microbes, Covid-19}

\begin{abstract}
Abstrak. Pandemi COVID-19 dapat mengancam jiwa manusia dan dapat menyebar secara masif apabila tidak ada tindakan pencegahan secara menyeluruh di semua negara termasuk Indonesia. Berbagai upaya diketahui dapat dilakukan untuk pencegahan penyebaran COVID ini termasuk salah satunya adalah penggunaan hand-sanitizer yang merupakan cairan antiseptik yang mampu untuk membunuh virus, bakteri, maupun jamur yang terdapat pada udara, alat-alat, dan tubuh manusia termasuk tangan. . Metode kegiatan yang dilakukan pada pengabdian kepada masyarakat ini adalah penyuluhan dengan menggunakan metode ceramah dengan menggunakan media slide power point yang berisi penjelasan mengenai pentingnya handsanitizer dan mendemonstrasikan langsung dengan swab tangan dari salah seorang masyarakat sebelum dan sesudah menggunakan handsanitizer lalu di goreskan pada media PDA (Potato Dextrose Agar). Kesimpulan dari pengabdian kepada masyarakat ini adalah masyarakat menjadi paham tentang pentingnya pengggunaan handsanitizer sebelum melakukan aktivitas karena melihat langsung bakteri yang tumbuh.
\end{abstract}

Kata Kunci: Pembersih tangan, mikroba, Covid-19

How to Cite: Sianipar, H. F., Siahaan, T. M., Mangapul Siahaan, M., \& Saragih, M. (2021). DISEMINASI HAND SANITIZER MAMPU MENGURANGI PERTUMBUHAN MIKROBA DI SIANTAR ESTATE. Mitra Mahajana: Jurnal Pengabdian Masyarakat, 2(1), 56-63. https://doi.org/10.37478/mahajana.v2i1.803

\section{PENDAHULUAN}

Corona virus adalah virus terbungkus RNA sense positif, mulai dari ukuran diameter 60 $\mathrm{nm}$ hingga $140 \mathrm{~nm}$ dengan spike like proyeksi di permukaannya memberikan penampilan seperti mahkota di bawah mikroskop elektron; karenanya dinamai virus corona. Ada empat virus korona yaitu HKU1, NL63, 229E dan OC43 telah beredar pada manusia, dan umumnya menyebabkan penyakit pernapasan ringan.

Corona virus telah menjadi pandemi di seluruh dunia, tak terkecuali di negara Indonesia. Masyarakat Indonesia perlu mengenal tanda-tanda virus COVID-19 sebagai langkah awal untuk mencegah penyebaran virus. Berikut beberapa gejala COVID-19: demam, batuk kering, kesulitan bernapas atau sesak napas, nyeri dada atau rasa tertekan pada dada, hilangnya kemampuan berbicara atau bergerak. Selain itu sebagai langkah pencegahan, masyarakat perlu memahami dan melaksanakan protokol kesehatan yang dianjurkan oleh pemerintah diantaranya: mencuci tangan /menggunakan hand sanitizer, menggunakan masker dan jaga jarak/physical distancing. Keadaan ini mempengaruhi kondisi tatanan bidang kesehatan, ekonomi, sosial, dan pendidikan (Kemendikbud, 2020). 
Kebersihan tangan merupakan hal yang terpenting dari kewaspadaan tiap orang dan merupakan metode yang paling awal dan efektif dalam mencegah penularan mikroba patogen yang berhubungan dengan kesehatan (WHO 2008). Usaha untuk menjaga tangan agar selalu bersih adalah salah satu langkah penting untuk mencegah penyakit dan mencegah penularan penyakit ke orang lain (CDC 2015). Centers for Disease Control and Prevention (CDC 2016) menyatakan bahwa penggunaan handsanitizer/pembersih tangan adalah cara terbaik untuk mengurangi jumlah mikroba di tangan, penggunaan handsanitizer lebih mudah dibandingkan mencuci tangan menggunakan sabun.

Hand Sanitizer merupakan pembersih tangan yang memiliki kemampuan antibakteri dalam menghambat hingga membunuh bakteri. Ada dua hand sanitizer yaitu hand sanitizer gel dan hand sanitizer spray. Hand sanitizer gel merupakan pembersih tangan berbentuk gel yang berguna untuk membersihkan atau menghilangkan kuman pada tangan, mengandung bahan aktif alkohol 60\%. Hand sanitizer spray merupakan pembersih tangan berbentuk spray untuk membersihkan atau menghilangkan kuman pada tangan yang mengandung bahan aktif irgasan DP 300 : 0,1\% dan alkohol 60\%. Hand sanitizer yang berbentuk cair atau spray lebih efektif dibandingkan hand sanitizer gel dalam menurunkan angka kuman pada tangan. Banyak hand sanitizer yang berasal dari bahan alkohol atau etanol yang dicampurkan bersama dengan bahan pengental, misal karbomer, gliserin, dan menjadikannya serupa jelly, gel atau busa untuk mempermudah dalam penggunaannya. Gel ini mulai populer digunakan karena penggunaanya mudah dan praktis tanpa membutuhkan air dan sabun. Gel sanitasi ini menjadi alternatif yang nyaman bagi masyarakat.

Seiring perkembangan zaman, dikembangkan juga pembersih tangan non alkohol, tetapi jika tangan dalam keadaan benar - benar kotor, baik oleh tanah, udara, darah, ataupun lainya, mencuci tangan dengan air dan sabun lebih disarankan karena gel hand sanitizer tidak dapat efektif membunuh kuman dan membersihkan material organik lainnya. Alkohol banyak digunakan sebagai antiseptik /desinfektan untuk desinfeksi permukaan kulit yang bersih, tetapi tidak untuk kulit yang luka. Selain itu alkohol juga mempunyai sifat iritasi pada kulit, mudah terbakar, dan juga meningkatkan infeksi virus pemicu radang saluran pencernaan, karena itu muncul ide untuk memanfaatkan bahan alami yang dapat mengurangi resiko munculnya penyakit gangguan pencernaan (Radji dkk, 2017).

Ada dua jenis pembersih tangan utama: berbahan dasar alkohol dan bebas alkohol. Pembersih tangan berbasis alkohol mengandung beragam jumlah dan jenis alkohol, seringkali antara 60 persen dan 95 persen dan biasanya isopropil alkohol, etanol (etil alkohol), atau npropanol. Alkohol diketahui dapat membunuh sebagian besar kuman Pembersih tangan bebas alkohol mengandung sesuatu yang disebut senyawa amonium kuarterner (biasanya benzalkonium klorida), bukan alkohol. Ini dapat mengurangi mikroba tetapi kurang efektif dibandingkan alkohol.

Pembersih tangan adalah alternatif yang mudah dan cepat saat mencuci tangan dengan sabun biasa dan air tidak nyaman atau tidak memungkinkan. Pembersih tangan seringkali memiliki bentuk alkohol, seperti etil alkohol, sebagai bahan aktif dan digunakan sebagai antiseptik. Banyak orang didunia ini termasuk Jutaan orang Amerika menggunakan produk HS setiap hari, terkadang beberapa kali sehari, untuk membantu mengurangi kuman di tangan mereka (WHO, 2020).

Kuman adalah suatu mahkluk hidup yang terdiri dari satu sel dan dapat memperbanyak diri dengan cepat,terutama bila terdapat pada suasana yang baik dan sesuai di dalam media dimana makanan tersedia untuk kuman. Satu kuman akan berkembangbiak menjadi sangat banyak dalam waktu yang singkat. Sebagai mahkluk hidup, kuman dapat mengeluarkan bahan bahan sisa dari hidupnya, berupa racun yang dapat membhayakan kelangsungan hidup manusia yang dihinggapi oleh kuman tersebut. Mikroba yang terdapat pada tangan biasanya berupa bakteri kapang, khamir, dan virus. Setiap orang memiliki rata - rata 150 bakteri atau kuman di telapak tangannya. Jenis kuman dalam jumlah besar yang terdapat di tangan adalah Helobacter 
pylori yang dapat menyebabkan maag, Escherichia coli yang dapat menyebabkan diare, Salmonella sp. Yang dapat menyebabkan tipus dan diare. Kuman yang lain seperti Stapylococcus aureus, Staphylococcus haemoliticus, Clostridium welchii, Pseudomonas spp., Staphylococcus aerugonisa, bakteri Coliform, Staphylococcus epidermis, Proteus spp, Klebsiella spp. dan Entamoeba coli (Rachmawati dan Yumna 2008).

Angka kuman adalah angka yang menunjukan adanya mikroorganisme patogen atau non patogen menurut pengamatan secara visual atau dengan kaca pembesar pada media penanaman yang akan diperiksa, kemudian dihitung berdasarkan lempeng dasar untuk standar tes terhadap bakteri atau jumlah bakteri mesofil dalam satu mililiter atau satu gram atau $\mathrm{cm} 2$ usap alat sampel yang diperiksa. Pada perhitungan angka kuman tidak dibedakan macam koloni. Tiap koloni berasal dari satu bakteri, sehingga tiap koloni dianggap satu bakteri.

Sebagian besar masyarakat di Siantar Estate, Kota Pematangsiantar mempunyai kegiatan sehari-hari sebagai buruh pabrik, dan di samping itulah melakukan aktifitas sosial terbatas dan kesempatan untuk mencuci tangan juga rendah. Salah satu alasan rendahnya tingkat membersihkan tangan di Siantar Estate yaitu kurangnya kepedulian terhadap kebersihan tangan dan malasnya setiap individual.

\section{METODE PELAKSANAAN}

Dalam teknis pelaksanaan, tim pengabdian masyarakat akan mendata kembali anggota kelompok yang akan mengikuti pembimbingan dan pendampingan program pengabdian pada masyarakat ini. Metode pelaksanaan dan pendekatan yang akan dikembangkan dalam kegiatan program PKM ini dapat mengatasi pola pikir tentang pentingnya pembersih tangan/handsanitizer.

Dalam program PKM ini. Kegiatan PKM ini dilaksanakan pada bulan September-Oktober 2020. Metode pelaksanaan program PKM ini meliputi dua hal yaitu sebagai berikut:

1. Metode Penyuluhan.

Metode penyuluhan merupakan salah satu metode yang akan dikembangkan dalam program PKM. Metode penyuluhan ini sangat penting pada anggota kelompok mitra untuk menambah pengetahuan sehingga terjadi perubahan kognitif. Artinya pola pikir yang dirubah terlebih dahulu untuk memudahkan proses kegiatan PKM selajutnya.

2. Metode Diseminasi

Mendiseminasikan langsung dengan swab tangan dari salah seorang masyarakat sebelum dan sesudah penggunaan pembersih tangan lalu di goreskan pada media PDA (Potato Dextrose Agar).

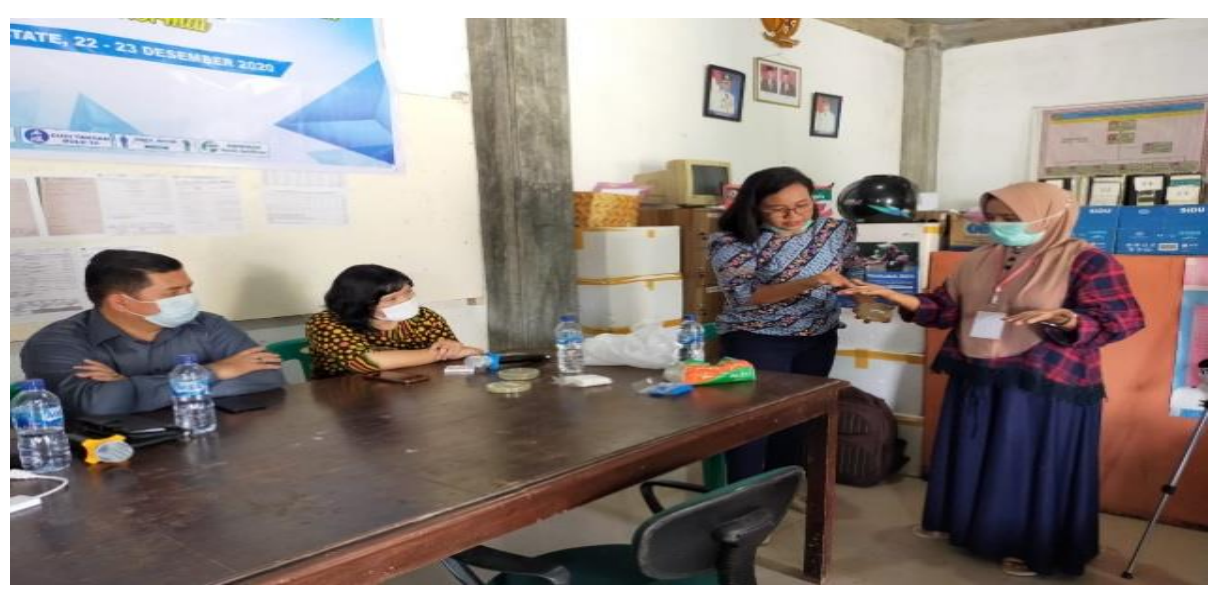

Gambar 1. Tim Pengabdi Mendemonstrasi Pentingnya Handsanitizer/Pembersih Tangan 


\section{HASIL DAN PEMBAHASAN}

Handsanitizer merupakan salah satu bahan antiseptik berupa gel yang sering digunakan masyarakat sebagai media pencuci tangan yang praktis. Penggunaan handsanitizer lebih efektif dan efisien bila dibanding dengan menggunakan sabun dan air sehingga masyarakat banyak yang tertarik menggunakannya. Adapun kelebihan hand sanitizer dapat membunuh kuman dalam waktu relatif cepat, karena mengandung senyawa alkohol (etanol, propanol, isopropanol) dengan konsentrasi $\pm 60 \%$ sampai $80 \%$ dan golongan fenol (klorheksidin, triklosan). Senyawa yang terkandung dalam hand sanitizer memiliki mekanisme kerja dengan cara mendenaturasi dan mengkoagulasi protein sel kuman. Alkohol sebagai disinfektan hanya mempunyai aktivitas bakterisidal saja, tetapi tidak terhadap virus dan jamur. Selain sebagai disinfektan, alkohol dalam Hand sanitizer dapat membantu melarutkan triklosan. Menurut hasil penelitian penelitian Rini (2018) bahwa antiseptik pada beberapa merk dengan kadar alkohol 60-70\% tanpa tambahan zat antibakteri lainnya memiliki sifat yang lebih polar, sehingga diameter daya hambat yang dihasilkan lebih besar pada bakteri Staphylococcus aureus.

Penyakit yang diakibatkan oleh tangan kotor dan dapat dicegah dengan mencuci tangan pakai pembersih tangan yaitu Diare menjadi penyebab kematian kedua yang paling umum untuk anak-anak balita. Penyakit diare seringkali diasosiasikan dengan keadaan air, namun secara akurat sebenarnya harus diperhatikan juga penanganan kotoran manusia seperti tinja dan air kencing, karena kuman-kuman penyakit penyebab diare berasal dari kotoran-kotoran ini. Kuman-kuman penyakit ini membuat manusia sakit ketika kuman masuk mulut melalui tangan yang telah menyentuh tinja, air minum yang terkontaminasi, makanan mentah dan peralatan makan yang tidak dicuci terlebih dahulu atau terkontaminasi akan tempat makannya yang kotor. Tingkat keaktifan mencuci tangan dengan sabun dalam penurunan angka penderita diare dalam persen menurut tipe inovasi pencegahan adalah mencuci tangan dengan sabun (44\%), penggunaan air olahan (39\%), sanitasi (32\%), pendidikan kesehatan (28\%), penyediaan air (25\%), sumber air bersih diolah (11\%).

Infeksi saluran pernafasan merupakan penyebab kematian utama untuk anak-anak balita. Mencuci tangan dengan sabun dapat mengurangi angka infeksi saluran pernafasan ini dengan dua langkah yaitu dengan melepaskan patogen-patogen pernafasan yang terdapat pada tangan dan permukaan telapak tangan dan dengan menghilangkan patogen (kuman penyakit) lainnya yang menjadi penyebab tidak hanya diare namun juga gejala penyakit pernafasan lainnya. Bukti-bukti telah ditemukan bahwa praktik-praktik menjaga kesehatan dan kebersihan seperti mencuci tangan sebelum dan sudah makan/buang air besar/kecil, dapat mengurangi tingkat infeksi hingga 25\%. Penelitian lain menemukan bahwa mencuci tangan dengan sabun mengurangi infeksi saluran pernafasan yang berkaitan dengan pneumonia pada anak-anak balita hingga lebih $50 \%$

Golongan fenol yang digunakan dalam hand sanitizer pada umumnya berupa triklosan dengan kadar $0,05 \%$ sampai dengan $2 \%$. Triklosan dapat memperlambat pertumbuhan bakteri juga bersifat antijamur dan antivirus serta bersifat kurang korosif. Berdasarkan penelitian Fitri (2016) bahwa pada berbagai merk sabun, diameter zona hambat yang lebih besar terdapat pada sabun D karena mengandung triklosan dan triklocarban juga menggunakan benzil alkohol sebagai bahan utamanya. Apabila antiseptik atau handsanitizer digunakan berlebihan dan terus menerus dapat berbahaya dan mengakibatkan iritasi hingga menimbulkan rasa terbakar pada kulit. Karena mengingat bahan dasar antiseptik tersebut berupa alkohol dan triklosan yang merupakan bahan kimia.

Infeksi covid-19 dapat menimbulkan gejala ringan, sedang, atau berat. Gejala klinis utama yang muncul yaitu deman (suhu $>38^{\circ} \mathrm{C}$ ), batuk dan kesulitan bernafas. Selain itu dapat di sertai dengan sesak memberat, fatigue, myalgia, gejala gastrointestinal seperti diare dan gejala saluran nafas lain. Setengah dari pasien timbul sesak dalam satu mingguan. Pada kasus berat perburukan secara cepat dan progresif, seperti ARDS, syok septik, asidosis metabolic yang sulit di koreksi dan perdarahan atau difungsi system koagulasi dalam beberapa hari. Pada beberapa 
pasien, gejala yang muncul ringan, bahkan tidak di sertai demam. Kebanyakan pasien memiliki prognosis baik, dengan sebagian kecil dalam kondisi kritis bahkan meninggal. Dari penjelasan tersebut mengingatkan kita bahwa sangat berbahayanya jika terinfeksi virus korona atau yang sering di sebut covid-19 ini (Setiat dkk, 2020).

Salah satu cara ampuh menangkal virus corona adalah dengan menjaga kebersihan tangan. Karenanya mencuci tangan dengan air mengalir sangatlah penting. Bila sedang tidak bisa cuci tangan dengan air dan sabun, bisa menggunakan hand sanitizer. Dari segi bahan-bahan dan pembuatan hand sanitizer ini pun sangat mudah yaitu menyiapkan daun sirih dan jeruk nipis. Air daun sirih sebanyak $15 \%$ ke atas sama efektifnya dengan etanol $70 \%$ untuk mengurangi jumlah bakteri dan virus. Sementara itu, daun sirih adalah bahan yang mudah mengalami oksidasi. Untuk menguranginya , air jeruk nipis yang bersifat anti-oksidan dan antibakteri dapat di tambahkan ke dalam air daun sirih tersebut (Telambuana, 2020).

Enam langkah mencuci tangan yang benar menurut WHO (2005) : a. Basahi kedua telapak tangan setinggi pertengahan lengan memakai air yang mengalir, ambil sabun kemudian usap dan gosok kedua telapak tangan secara lembut. b. Usap dan gosok juga kedua punggung tangan secara bergantian, jari -jari tangan, gosok sela-sela jari hingga bersih.

Bersihkan ujung jari secara bergantian dengan cara mengatupkan. d. Gosok dan putar kedua ibu jari secara bergantian. e. Letakkan ujung jari ke telapak tangan kemudian gosok perlahan. f. Bersihkan kedua pergelangan tangan secara bergantian dengan cara memutar, kemudian diakhiri dengan membilas seluruh bagian tangan dengan air bersih yang mengalir lalu keringkan memakai handuk atau tisu. Ada lima waktu penting cuci tangan (Dinkes Bengkulu,2014) yaitu: a. Sebelum makan b. Sesudah buang air besar c. Sebelum memegang bayi d. Sesudah menceboki anak e. Sebelum menyiapkan makanan.

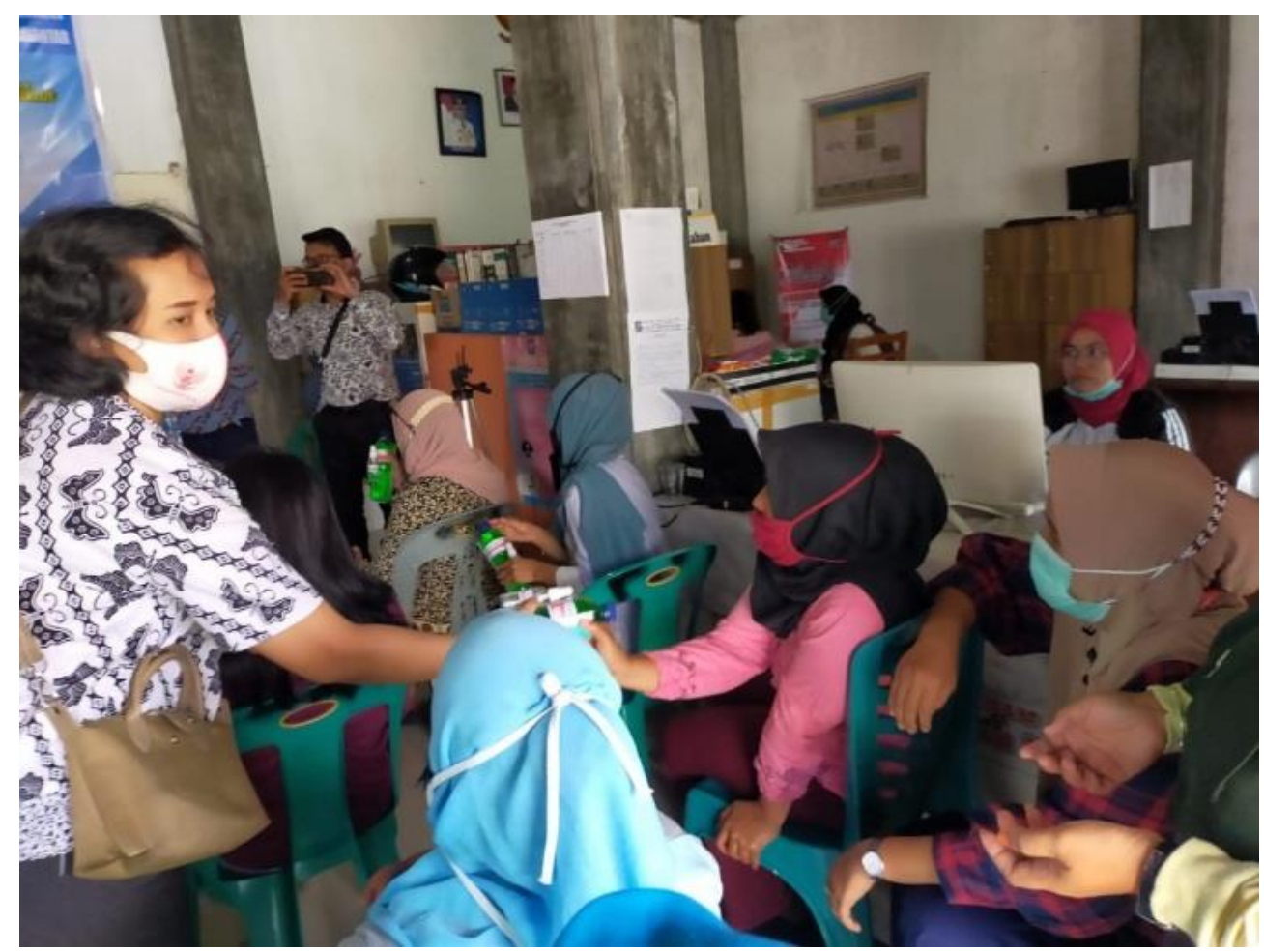

Gambar 2. Tim Pengabdi Membagikan Alat Protokol Kesehatan

Dari hasil diseminasi yang dilakukan tim pengabdi tentang pentingnya cuci tangan menggunakan sabun, dapat dilihat mikroba yang tumbuh pada media PDA. 


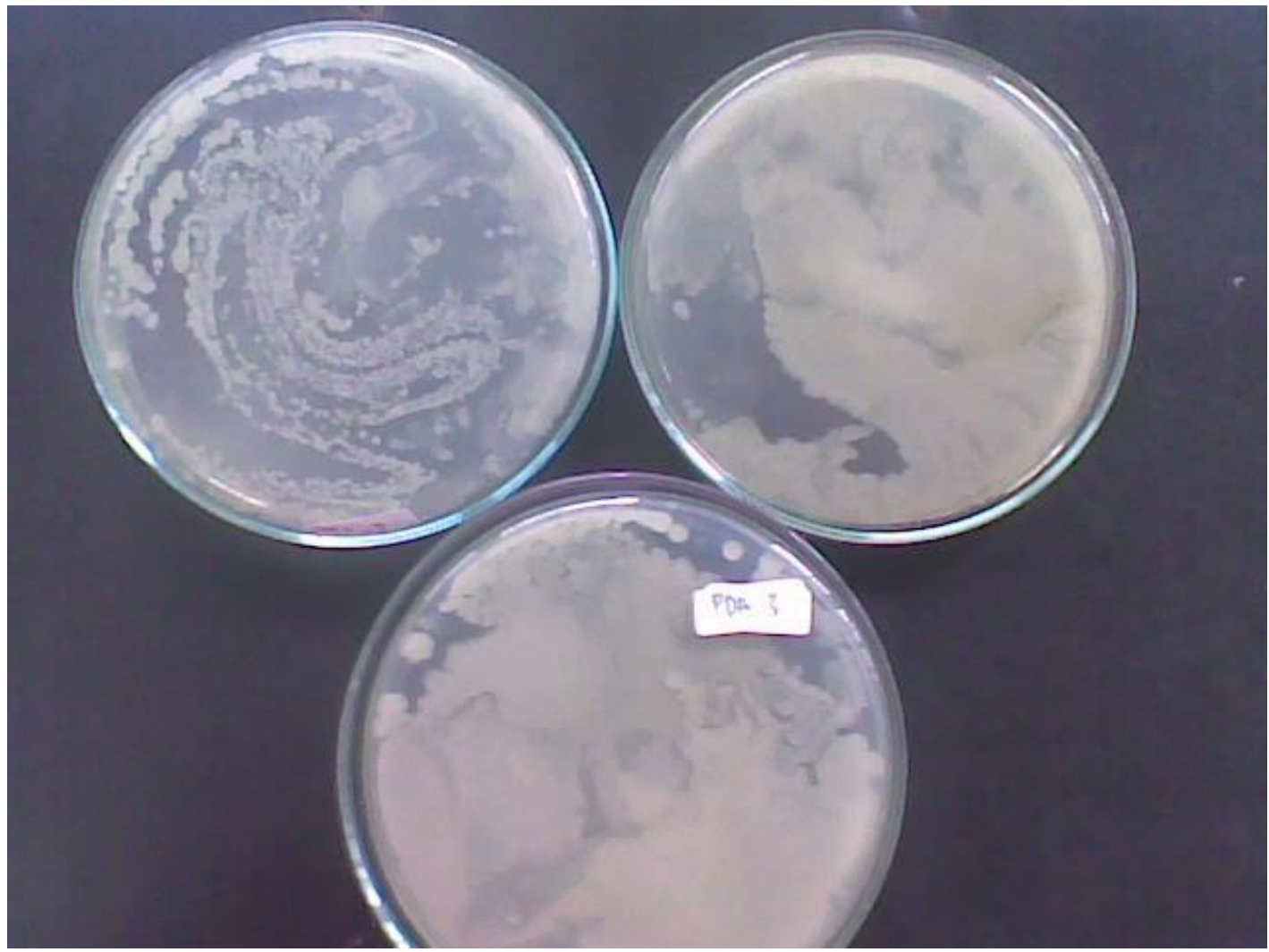

Gambar 3. Perbedaan Mikroba yang tumbuh pada media yang tangannya sebelum dan sesudah penggunaan handsanitizer

Dari gambar 2 dapat dilihat bahwa mikroba yang tumbuh pada pada media PDA tanpa menggunakan handsanitizer > 1000 koloni, sedangan media PDA dengan menggunakan handsanitizer < 100 koloni. Hasil penelitian menunjukkan bahwa mencuci tangan menggunakan air biasa tidak mempengaruhi hasil uji bakteri. Hal ini dikarenakan air biasa yang digunakan untuk mencuci jari tangan tidak memiliki kandungan senyawa zat aktif yang mampu membunuh bakteri. Pada perlakuan setelah pengaplikasian handsanitizer pada jari tangan membuktikan adanya penurunan jumlah koloni bakteri, sehingga membuktikan bahwa terdapatnya senyawa zat aktif yang mampu untuk membunuh bakteri.

Hasil ini menunjukan bahwa perlakuan mencuci tangan dengan menambahkan zat anti kuman atau desinfektan memberikan pengaruh yang signifikan terhadap jumlah angka kuman. Pada perlakuan mencuci tangan tanpa pemberian zat anti kuman, jumlah angka kuman masih tinggi, sedangkan pada perlakuan mencuci tangan dengan menambahkan zat anti kuman jumlah angka kuman menjadi lebih rendah, sehingga mean angka kuman untuk setiap perlakuan mencuci tangan dengan menambahkan zat anti kuman hampir sama atau tidak ada perbedaan yang signifikan. Perlakuan cuci tangan dengan air mengalir hasilnya tidak signifikan, hal tersebut berarti dapat disimpulkan bahwa perlakuan cuci tangan dengan air mengalir tidak efektif, sedangkan kelompok perlakuan cuci tangan dengan sabun, lebih efektif dalam penurunan jumlah angka kuman. Hal ini bisa dilihat dari rerata jumlah angka kuman ketiga perlakuan tersebut yang lebih rendah dibandingkan dengan kelompok kontrol.

Perlakuan cuci tangan dengan hand sanitizer secara statistik sama-sama efektif, akan tetapi secara deskriptif perlakuan cuci tangan dengan hand sanitizer lebih efektif karena mempunyai rerata jumlah angka kuman paling rendah. Cuci tangan yang baik adalah mencuci tangan dengan menggunakan sabun plain (tidak mengandung anti mikroba) atau sabun antiseptik yang mengandung anti mikroba, menggosok-gosok kedua tangan meliputi seluruh permukaan tangan dan mencucinya dengan air mengalir dan mengeringkannya secara keseluruhan dengan menggunakan handuk sekali pakai. Kebersihan pribadi dan pembersihan 
rutin sangat penting untuk kesehatan yang baik. Sering mencuci tangan dengan cara yang baik adalah kunci untuk mencegah penyebaran mikroorganisme (juga dikenal sebagai mikroba atau kuman) yang menyebabkan penyakit umum, dan pembersihan secara teratur permukaan tangan dapat menghilangkan partikel kotoran dan makanan di mana kuman dapat tumbuh.

Handsanitizer merupakan bahan kimia yang mencegah multiplikasi organisme pada permukaan tubuh, dengan cara membunuh mikroorganisme tersebut atau menghambat pertumbuhan dan aktivitas metaboliknya. Antiseptik perlu dibedakan dengan antibiotik yang membunuh mikroorganisme dalam tubuh makhluk hidup, dan desinfektan yang membunuh mikroorganisme pada benda mati. Namun antiseptik sering pula disebut sebagai desinfektan kulit. Hampir semua bahan kimia yang dipakai sebagai antiseptik dapat pula berperan sebagai desinfektan. Hal ini ditentukan oleh konsentrasi bahan tersebut. Biasanya konsentrasi bahanyang digunakan sebagai antiseptik lebih rendah daripada desinfektan. Dalam penelitian ini, suatu cairan pembersih tangan antiseptik (hand sanitizer) dikatakan efektif yaitu apabila pada perlakuan tersebut mempunyai mean (rerata) jumlah angka kuman yang terendah dibandingkan dengan kontrol.

Konsentrasi terbaik alkohol sebagai antiseptik adalah 60-80\%. Konsentrasi alkohol lebih tinggi mengurangi kemampuannya dalam mendenaturasi protein karena denaturasi protein membutuhkan air. Sehingga dalam pemilihan hand sanitizer sebagai alternatif untuk mencuci tangan, perlu dipertimbangkan komposisinya agar dalam pemakaiannya benar-benar efektif terhadap penurunan jumlah angka kuman pada tangan.1 Selain perlakuan menggunakan hand sanitizer, pada penelitian ini juga menggunakan perlakuan mencuci tangan menggunakan air mengalir dan sabun sebagai pembanding. Hasil rerata jumlah angka kuman mencuci tangan menggunakan air mengalir lebih tinggi dibandingkan dengan mencuci tangan menggunakan sabun dan hand sanitizer karena di dalam air mengalir tidak terkandung zat anti kuman. Pada perlakuan mencuci tangan menggunakan air mengalir, hasil rerata jumlah angka kuman hampir sama dengan kelompok kontrol, tetapi lebih sedikit dikarenakan pada waktu mencuci tangan menggunakan air mengalir, kuman ikut terbawa oleh air yang mengalir meskipun tidak seefektif apabila ditambahkan dengan sabun atau pun dengan zat antiseptik lainnya. Air dan sabun adalah campuran inti untuk menyingkirkan kotoran. Sebagian besar kotoran yang melekat pada pakaian atau kulit melekat sebagai minyak yang tipis.

Lapisan minyak ini akan terangkat saat dicuci. Sedangkan hand sanitizer mengandung alkohol sebagai bahan utama pembersih tangan. Alkohol juga mempunyai efek bakterisidal yang cepat terhadap bakteri vegetatif gram positif dan gram negatif, MRSA, M.tuberkulosis, beberapa jenis jamur, non-envelope virus. Alkohol bekerja pada bakteri dengan cara mendenaturasi protein dan menghancurkan membran sitoplasma bakteri. E.coli merupakan bakteri vegetatif gram negatif berbentuk kokobasil yang mempunyai peptidoglikan tipis pada dinding sel nya dan dua lapis posfolipid pada membran sitoplasmanya, sehingga alkohol bisa bekerja pada E.coli dengan mendenaturasi protein pada membran sitoplasma.

Dari pelaksanaan pengabdian kepada masyarakat berupa penyuluhan dan demonstrasi ini dapat dilihat bahwa sebagian besar peserta penyuluhan (75\%) belum pernah mendapatkan penyuluhan tentang protokol kesehatan dari langkah awal cuci tangan pakai sabun, Keberhasilan pelaksanaan pengabdian kepada masyarakat ini dapat dilihat dari ketercapaian target jumlah peserta, ketercapaian tujuan dan ketercapaian target materi. Peserta yang hadir adalah 33 orang, dari target peserta 40 orang (82,5\%). Ketercapaian target materi dapat dikatakan cukup baik (100\%) dilihat dari semua materi penyuluhan dapat disampaikan oleh tim pengabdi kepada ibu-ibu peserta penyuluhan dan selain itu juga dilihat dari ibu-ibu peserta dapat menjawab pertanyaan-pertanyaan dari tim pengabdi Di akhir acara, tim pengabdi dan ibu-ibu peserta kegiatan berikrar untuk menggalakkan penggunaan handsanitizer mulai dari rumah hingga lingkungan agar tercipta perilaku hidup bersih dan sehat. 


\section{SIMPULAN DAN TINDAK LANJUT}

Kesimpulan dari pengabdian kepada masyarakat ini adalah masyarakat menjadi paham tentang pentingnya pemakaian hand sanitiser disertai pemahaman penggunaan dan manfaatnya kepada minimal 40 orang sasaran. Dan masyarakat memberikan respon yang sangat baik dengan indikator capaian yaitu mereka langsung memakai handsanitiser sesuai tujuan dan fungsinya.

\section{DAFTAR PUSTAKA}

Depkes. (2017). Cuci Tangan Pakai Sabun Cegah Kematian Anak .http://www.depkes.go.id/article/view/17101600001/cuci-tangan-pakai-sabun-cegahkematiananak.html. (Diakses 2 Desember 2020).

Fitri, L. (2016). Kemampuan Daya Hambat Beberapa Macam Sabun Antiseptik Terhadap Pertumbuhan Staphylococcus aureus dan Escherichia coli. Biology, 1(2), 1-7.

Kemendikbud. 2020. Surat Edaran Nomor 4 Tahun 2020 tentang Pelaksanaan Kebijakan Pendidikan dalam Masa Darurat Penyebaran Covid-19.

Radji, M., Suryadi, H., Ariyanti, D. 2017. Uji Efektivitas Antimikroba Beberapa Merek Dagang Pembersih Tangan Antiseptik, Majalah Ilmu Kefarmasian, 4(1), 1-6, Departemen Farmasi FMIPA-UI, Depok.

Rachmayanti. 2009. Penggunaan Media Panggung Boneka dalam Pendidikan Personal Hygiene Cuci Tangan Menggunakan Sabun di Air Mengalir, Jurnal Promosi Kesehatan, 1(1), 1-13, Universitas Airlangga, Surabaya. 2009.

Rini, E. P., \& Nugraheni E. R. (2018). Uji Daya Hambat Berbagai Merek Handsanitizer Gel Terhadap Pertumbuhan Bakteri Escherichia coli dan Staphylococcus aureus. Journal of Pharmaceutical Science and Clinical Research, 1(10), 18-26.

Setiati, S., \& Azwar, M. K. (2020). COVID19 and Indonesia. Acta Medica Indonesiana, (April), 8389.

Telaumbanua, D. (2020). Urgensi Pembentukan Aturan Terkait Pencegahan Covid-19 di Indonesia. Qalamuna - Jurnal Pendidikan, Sosial, Dan Agama, 12(1), 59- 70. .

WHO. (2020). Coronavirus disease 2019 ( COVID-19). World Health Organization 